\title{
The preS1 Antigen of Hepatitis B Virus Is Highly Immunogenic at the T Cell Level in Man
}

\author{
C. Ferrari, ${ }^{\star \star}$ A. Penna, ${ }^{\star}$ A. Bertoletti, ${ }^{\star}$ A. Cavalli," A. Valli, ${ }^{\star}$ C. Schianchi, ${ }^{\star}$ and F. Fiaccadori \\ *Cattedra di Malattie Infettive, Universita’ di Parma, 43100 Parma, Italy; and ${ }^{\ddagger}$ Research Institute of Scripps Clinic, \\ Department of Molecular and Experimental Medicine, La Jolla, California 92037
}

\begin{abstract}
14 hepatitis B vaccine recipients who showed high titers of anti-hepatitis B surface antibodies in serum after booster immunization with a polyvalent hepatitis $B$ surface antigen vaccine that contained trace amounts of hepatitis B virus (HBV) preS1 and preS2 envelope antigens were studied for their in vitro $T$ cell response to these antigens. All 14 subjects displayed a significant proliferative $T$ cell response to the $S / p 25$ envelope region encoded polypeptide; 8 also responded to preS1, while only 1 showed a significant level of $T$ cell proliferation to preS2. Limiting dilution analysis demonstrated that the frequency of preS-specific $T$ cells in two of these vaccine recipients was higher than that of $S / p 25-$ specific $T$ cells. $T$ cell cloning was then performed and a total of $29 \mathrm{HBV}$ envelope antigen-reactive CD4+ cloned lines were generated from two preS-responsive vaccinees. 21 of these lines were S/p25 specific, 7 preS1 specific, and 1 preS2 specific. Taken together, all these results suggest that the preS1 antigen may function as a strong $\mathbf{T}$ cell immunogen in man.
\end{abstract}

\section{Introduction}

Existing vaccines against hepatitis $B$ consist of either $20 \mathrm{~nm}$ hepatitis B surface antigen (HBsAg) ${ }^{1}$ particles derived from plasma of chronic HBsAg carriers (1), or $\mathrm{HBsAg}$ produced by recombinant DNA technology (2).

Several lines of evidence suggest that inclusion of the preS sequence of the hepatitis B virus (HBV) envelope into these immunogens should improve the efficacy of the vaccination, inducing a wider spectrum of antiviral antibodies.

Since the preS1 and preS2 regions of the HBV envelope may contain the hepatocyte receptor binding site $(3,4)$, the immune response to these antigens may play an important role in the prevention of and recovery from HBV infection. In support of this hypothesis, it has been shown that anti-preS1 and anti-preS2 antibodies appear early during HBV infection, before the detection of anti-hepatitis B surface antibodies

Address reprint requests to Dr. Carlo Ferrari, Cattedra Malattie Infettive, Universita' di Parma, Via Gramsci 14, 43100 Parma, Italy.

Received for publication 29 August 1988 and in revised form 31 May 1989.

1. Abbreviations used in this paper: anti-HBs, anti-hepatitis B surface antibodies; APC, antigen-presenting cells; ARC, antigen responsive cells; h, human; $\mathrm{HBcAg}$, hepatitis B core antigen; $\mathrm{HBsAg}$, hepatitis B surface antigen; HBV, hepatitis B virus; $r$, recombinant; SI, stimulation index; TT, tetanus toxoid.

J. Clin. Invest.

(c) The American Society for Clinical Investigation, Inc. 0021-9738/89/10/1314/06 \$2.00

Volume 84, October 1989, 1314-1319
(anti-HBs; 5-9). Their appearance is usually followed by recovery from HBV infection. In contrast, anti-preS antibodies are exceptionally rare in chronic hepatitis $B(6,7)$. In addition, immune response to preS antigens may circumvent nonresponsiveness to the $S$ region of $\mathrm{HBV}$ envelope in strains of HBsAg nonresponder mice (10-12); furthermore, chimpanzees immunized with a synthetic preS2 peptide appeared to be protected from HBV infection (13).

Because the Pasteur vaccine (Hevac-B) contains small quantities of preS sequences ( $\leq 20 \mathrm{ng} / \mu \mathrm{g} \mathrm{HBsAg}$; 14), production of anti-preS antibodies in recipients of this vaccine has been investigated, and the results of such studies suggest that the preS antigens are highly immunogenic in man at least in terms of specific antibody elicitation $(9,15)$. In contrast, very little is known about the human $\mathrm{T}$ cell response to preS antigens after vaccination or natural HBV infection (16-20).

In the present study the $T$ cell response to the $S$, preS2, and preS 1 antigens of the HBV envelope has been studied in recipients of the Pasteur vaccine using a series of well-characterized plasma-derived and recombinant antigen preparations consisting of various combinations of $\mathrm{HBV}$ envelope region encoded polypeptides. Our data show that immunization with very low amounts of preS1 may induce in some individuals high levels of $\mathrm{T}$ cell sensitization, suggesting that the preS1 molecule may function as a strong $\mathrm{T}$ cell immunogen in man.

\section{Methods}

14 subjects immunized with plasma-derived hepatitis B vaccine (Hevac-B; Pasteur), without anamnestic, biochemical, or immunological evidence of previous exposure to HBV, were studied. Control experiments were performed on 15 age- and sex-matched healthy, nonimmunized subjects who were negative for $\mathrm{HBsAg}$, anti-HBs, and antibody to hepatitis B core antigen. $\mathrm{HBsAg}$, anti-HBs, and antibodies to hepatitis $B$ core antigen were determined by commercially available enzyme immunoassay kits (Abbott Laboratories, North Chicago, IL).

$H B V$ envelope antigen preparations. A purified preparation containing the $S$, preS1, and preS2 region encoded determinants was provided by Sorin Biomedica (Saluggia, Italy), and obtained from pooled HBsAg-positive serum of ad and ay subtypes derived from chronic HBsAg carriers as previously described (16). By solid-phase RIA, levels of preS2 and preS1 reactivities in this antigen preparation were about 8 and $1 \%$ of the total $\mathrm{HBsAg}$ reactivity, respectively. We will refer to this antigen as human (h) $\mathrm{S}+$ preS2+preS1.

Two plasma-derived preparations of $\mathrm{HBsAg}$ of different subtype (ad or ay) composed exclusively of the 25-kD S region encoded polypeptide (S/p25) without preS region encoded determinants (21), were provided by R. Louie (Cutter Laboratories, Berkeley, CA). They are herein designated as $\mathrm{hS} / \mathrm{p} 25$.

A recombinant, yeast-derived preparation of $\mathrm{HBsAg(ay)}$ containing the $S / p 25$ polypeptide exclusively was provided by Amgen (Thousand Oaks, CA) and is herein designated as recombinant (r) S/p25.

Two recombinant, yeast-derived preparations containing either S/p25 plus preS2 (rS+preS2; subtype ad; 22) or S/p25 plus preS2 plus preS1 (rS+preS2+preS1; subtype ay; 23) and two synthetic peptides consisting of either the entire preS1 region (108 amino acid residues, subtype ay) or the entire preS2 region (55 amino acids, subtype ad) 
were provided by R. W. Ellis (Merck Sharp and Dohme Research Laboratories, West Point, PA).

Recombinant hepatitis B core antigen (HBcAg; Sorin Biomedica, Saluggia, Italy) and tetanus toxoid (TT; Massachusetts State Department of Public Health) were used as control antigens.

Isolation of $H B V$ envelope antigen-reactive $T$ cell lines and clones. PBMC were cultured in RPMI 1640 medium supplemented with 25 $\mathrm{mM}$ Hepes, $2 \mathrm{mM}$ L-glutamine, $50 \mu \mathrm{g} / \mathrm{ml}$ gentamycin, and $10 \%$ heatinactivated human $\mathrm{AB}$-positive serum (complete medium) in the presence of $\mathrm{hS}+$ preS2+preS1 $(1 \mu \mathrm{g} / \mathrm{ml})$. After $7 \mathrm{~d}$ incubation at $37^{\circ} \mathrm{C}$ in a humidified atmosphere of $5 \% \mathrm{CO}_{2}$ in air, activated lymphocytes were initially plated at 10 cells/well in round-bottomed, 96-well plates in RPMI 1640 medium containing 10\% FCS in the presence of HBV envelope antigens ( $\mathrm{hS}+$ preS2+preS1; $1 \mu \mathrm{g} / \mathrm{ml}$ ), rIL-2 (Hoffman La Roche, Basel, Switzerland), and mytomicin C-treated (45 min at $37^{\circ} \mathrm{C} ; 50 \mu \mathrm{g} / \mathrm{ml}$ ) autologous PBMC as antigen-presenting cells (APC; 1 $\times 10^{5} /$ well). Growing cloned $\mathrm{T}$ cell lines were expanded in medium containing rIL-2 and restimulated weekly with antigen and autologous APC.

Selected cloned $\mathrm{T}$ cell lines were subcloned at the concentration of 0.5 cells/well as described above.

The probability for each positive well being a clone derived from a single precursor was calculated by means of a conditional probability argument (24) assuming Poisson statistics (25).

$T$ cell proliferation assay. For the study of the proliferative response of purified peripheral blood $\mathrm{T}$ cells to $\mathrm{HBV}$ envelope antigens, $\mathrm{T}$ cells and non-T cells were isolated by the E-rosette technique (16).

Purified T cells $\left(1 \times 10^{5}\right)$ cocultured with $1 \times 10^{4}$ mytomicin C-treated autologous non-T cells as APC were incubated in complete medium for $7 \mathrm{~d}$ at $37^{\circ} \mathrm{C}$ in an atmosphere of $5 \% \mathrm{CO}_{2}$ and $95 \%$ air in the presence of different concentrations $(0.01,0.1$, or $1 \mu \mathrm{g} / \mathrm{ml})$ of $\mathrm{hS} / \mathrm{p} 25$, preS1, or preS2 peptides.

For the study of $\mathrm{T}$ cell lines and clones, cloned $\mathrm{T}$ cells were washed extensively to remove IL-2 and FCS. Subsequently, $5 \times 10^{4}$ cells/well were incubated for $3 \mathrm{~d}$ with $1 \times 10^{5}$ mytomicin C-treated autologous PBMC as APC in complete medium in the presence of different concentrations of HBV envelope antigens, rHBcAg, or TT.

All proliferation assays were performed in triplicate and $\left[{ }^{3} \mathrm{H}\right]-$ thymidine $(0.5 \mu \mathrm{Ci} /$ well; $\mathrm{sp}$ act, $2.0 \mathrm{Ci} / \mathrm{mmol}$; Amersham International, Amersham, UK) was added $18 \mathrm{~h}$ before harvesting. The results are expressed as the mean counts per minute of three replicate determinations and as the stimulation index (SI); that is, the ratio between mean counts per minute incorporated in the presence of antigen and mean counts per minute obtained in the absence of antigen.

Determination of the frequency of $H B V$ envelope antigen-responsive $T$ cells. Peripheral blood HBV envelope antigen-specific $\mathrm{T}$ cell frequency was determined by limiting dilution analysis. Varying numbers of purified T cells $\left(1 \times 10^{5}, 6 \times 10^{4}, 3 \times 10^{4}, 1 \times 10^{4}, 3 \times 10^{3}, 1 \times 10^{3}\right.$, and $3 \times 10^{2}$ ) were seeded in individual wells of round-bottomed, 96well plates in the presence of a constant number of autologous mytomicin C-treated non- $\mathrm{T}$ cells $\left(1 \times 10^{4}\right)$ and an optimal dose of antigen $(1 \mu \mathrm{g} / \mathrm{ml})$.

32 replicate wells were set up for each concentration of responder $T$ cells in the presence or absence of antigen. $\left[{ }^{3} \mathrm{H}\right]$ Thymidine incorporation was measured after $7 \mathrm{~d}$ of incubation. Individual cultures stimulated with antigen, showing $\left[{ }^{3} \mathrm{H}\right]$ thymidine incorporation higher than the arithmetic mean plus 3 SD of that shown by cultures incubated in the absence of antigen were scored as positive and the fraction of nonresponder cultures was calculated for each concentration of seeded $\mathrm{T}$ cells.

Statistical analysis. Poisson analysis was applied for the calculation of $T$ cell frequency $(25,26)$. Assuming that antigen responsive cells (ARC) are randomly and independently distributed through the culture wells, the number of ARC per well follows a Poisson distribution.

The Poisson formula, $\mathrm{F}_{r}=\frac{u^{r}}{r !} \times \mathrm{e}^{-u}$, is the probability of obtaining $r$ ARC in any particular well when the mean number of ARC plated per well is $u$.
After performing a limiting dilution assay, one may plot the natural logarithm of the fraction of negative wells against number of cells per well plated; a straight line is expected if single-hit Poisson kinetics are operative. In this instance, one may then estimate the Poisson parameter $u$, and thereby the frequency of ARC. We used the ELIDA program of C. Taswell (26), which incorporates linear regression analysis, for this estimation procedure.

\section{Results}

Peripheral blood $T$ cell proliferative response to $H B V$ envelope antigens. The response of peripheral blood $\mathrm{T}$ cells to plasmaderived S/p25 and synthetic preS1 and preS2 peptides was studied in 14 selected vaccine recipients who developed high titers of serum anti-HBs after booster immunization (anti-HBs titers $\geq 1: 100,000$ ).

All 14 subjects displayed a significant $T$ cell proliferative response to $\mathrm{S} / \mathrm{p} 25 ; 8$ responded to preS1, while only 1 showed a significant level of $\mathrm{T}$ cell proliferation to preS2 (Table I).

No significant level of T cell proliferation to the HBV envelope antigens used in this study was observed in the 15 control subjects.

Frequency of $H B V$ envelope antigen-responsive $T$ cells. Limiting dilution analysis was performed $\sim 1$ mo after booster immunization on peripheral blood $\mathrm{T}$ cells derived from vaccine recipients 3 and 12 (Table I).

Table I. Proliferative Response of Peripheral Blood T Cells to Plasma-derived S/p25, preS1 (1-108), and preS2 (1-55) Synthetic Peptides in Hepatitis B Vaccine Recipients

\begin{tabular}{|c|c|c|c|}
\hline \multirow[b]{2}{*}{ Vaccine recipient } & \multicolumn{3}{|c|}{ Cell proliferation $(\mathrm{SI})^{*}$} \\
\hline & $\begin{array}{l}\mathrm{hS} / \mathrm{p} 25 \\
\text { (ad) }\end{array}$ & $\begin{array}{c}\text { preS1 } \\
\text { (peptide) }\end{array}$ & $\begin{array}{c}\text { preS2 } \\
\text { (peptide) }\end{array}$ \\
\hline 1 & $\underline{9.8}$ & $\underline{3.3}$ & 1.5 \\
\hline 2 & $\underline{5.1}$ & $\underline{3.1}$ & 1.5 \\
\hline 3 & $\overline{9.7}$ & $\underline{5.1}$ & 1.1 \\
\hline 4 & $\underline{13.4}$ & $\underline{5.1}$ & $\underline{7.4}$ \\
\hline 5 & $\underline{3.8}$ & 1.7 & 1.8 \\
\hline 6 & $\underline{12.2}$ & 1.1 & 1.1 \\
\hline 7 & $\underline{14.6}$ & 1.5 & 1.7 \\
\hline 8 & $\overline{4.7}$ & 1.1 & 0.8 \\
\hline 9 & $\overline{4.6}$ & 1.3 & 0.8 \\
\hline 10 & $\underline{27}$ & $\underline{8.4}$ & 1.6 \\
\hline 11 & $\underline{13}$ & 1.5 & 0.7 \\
\hline 12 & $\underline{11}$ & $\underline{7.4}$ & 1.5 \\
\hline 13 & $\overline{12.4}$ & $\underline{3.1}$ & 1.9 \\
\hline 14 & $\underline{4.6}$ & $\underline{4.9}$ & 1.5 \\
\hline $\begin{array}{c}\text { Mean } \pm \text { SEM } \\
(n=14)\end{array}$ & $10.43 \pm 1.65$ & $3.47 \pm 0.63$ & $1.7 \pm 0.45$ \\
\hline Control mean \pm SEM & $\begin{array}{l}1.04 \pm 0.12 \\
(n=15)\end{array}$ & $\begin{array}{c}1.08 \pm 0.07 \\
(n=15)\end{array}$ & $\begin{array}{c}1.15 \pm 0.08 \\
(n=14)\end{array}$ \\
\hline $\begin{array}{l}\text { Vaccine recipients } \\
\text { vs. controls }{ }^{\ddagger}\end{array}$ & $P<0.001$ & $P<0.01$ & NS \\
\hline
\end{tabular}

* Values represent the proliferative response obtained with $1 \mu \mathrm{g} / \mathrm{ml}$ of antigen. SI is the ratio between $\left[{ }^{3} \mathrm{H}\right]$ thymidine incorporation in the presence and absence of antigen. Values of SI higher than mean SI plus 3 SD of the controls were considered significant increases of proliferation. Underlined values correspond to significant proliferative responses.

‡ SI values have been used for statistical analysis. 
Frequency of circulating $\mathrm{S}$ and preS1-specific $\mathrm{T}$ cells was studied in recipient 12 using the plasma-derived $S / p 25$ antigen preparation and the preS1 synthetic peptide (1-108). Frequency of preS2-reactive $T$ cells was not determined since peripheral blood $\mathrm{T}$ cells from this subject appeared to be responsive to S/p25 and preS1 but not to preS2 (Table I).

Limiting dilution analysis of $\mathrm{T}$ cells from vaccine recipient 3 (see Table I) was performed using hS/p25 and the plasma-derived antigen preparation containing $\mathrm{S}+$ preS2+preS1 used for $T$ cell cloning.

The antigen concentration of $1 \mu \mathrm{g} / \mathrm{ml}$ was used since preliminary experiments showed that optimal peripheral blood $\mathrm{T}$ cell proliferation was usually elicited by this antigen concentration. In vaccine recipient 12 the frequency of circulating preS1 and S/p25-responsive T cells was 1 in 16,155 and 1 in 35,335 , respectively. In vaccine recipient $12 \mathrm{~S} / \mathrm{p} 25$-responsive $\mathrm{T}$ cells were 1 in $59,311 \mathrm{~T}$ cells, whereas $\mathrm{S}+\mathrm{preS} 2+$ preS1-responsive $\mathrm{T}$ cells were 1 in 16,750 (Fig. 1).

Generation of $H B V$-envelope antigen-specific $T$ cell lines. Two vaccine recipients (subjects 4 and 12 of Table I) who displayed a strong $\mathrm{T}$ cell proliferation to $\mathrm{HBV}$ envelope antigens were selected for clonal analysis of the $T$ cell response. 118 cloned lines (42 from subject 12 and 76 from subject 4 ) were generated and tested for proliferative response to $\mathrm{hS}+$ preS2+preS1. 29 (14 from subject 12 and 15 from subject 4) displayed a dose-dependent $(0.01-5 \mu \mathrm{g} / \mathrm{ml})$ proliferation to HBV envelope antigens (Table II and Fig. 2) and their antigen specificity was confirmed by the absence of response to rHBcAg and TT (data not shown).

Cell surface analysis of the HBV envelope antigen-specific $T$ cell lines revealed that all were $\mathrm{CD} 3+, \mathrm{CD} 4+$, or CD8-.

$H B V$ envelope region specificity of the $T$ cell cloned lines. Antigen specificity of the $29 \mathrm{HBV}$ envelope antigen responsive
T cell cloned lines was analyzed further by testing their capacity to recognize antigen preparations containing only $S / p 25$ without preS region encoded determinants. 21 lines (72\%) showed a significant level of proliferative response upon stimulation with plasma-derived S/p25 of ad subtype; 13 were also tested with $\mathrm{rS} / \mathrm{p} 25$ of ay subtype and all showed comparable levels of response (Table II). Identical results were also obtained with four of these lines using an additional plasma-derived antigen preparation containing S/p25 of ay subtype (data not shown). This observation indicated that these cloned lines recognized common epitopes shared by the ad and ay subtypes of HBsAg, in keeping with previous reports (28). In contrast, eight lines (28\%) did not proliferate to $\mathrm{S} / \mathrm{p} 25$ of ad or ay subtypes at all the antigen concentrations tested $(0.01,0.1$, or $1-5$ $\mu \mathrm{g} / \mathrm{ml}$; Table II).

Two different recombinant preparations consisting of either $\mathbf{S}+$ preS2 or $\mathbf{S}+$ preS2 + preS1 were used to investigate further the antigen specificity of the S/p25 nonresponsive lines. All five S/p25 nonresponsive lines from subject 12 and two $\mathrm{S} / \mathrm{p} 25$ nonresponsive lines from subject 4 did not proliferate to antigen preparations containing preS2 without preS1 determinants, whereas all of them displayed a dose-dependent proliferation to rS+preS2+preS1 (Table III and Fig. 2). These results showed that these lines were preS1 specific.

In contrast, one $S / p 25$ nonresponsive line from subject 4 responded equally well to both recombinant preparations, suggesting that this line was probably preS2 specific.

The preS region specificity of the $S / p 25$ nonresponsive lines was finally confirmed using preS1 and preS2 synthetic peptides. Six of seven tested lines showed selective proliferation to the synthetic peptide consisting of the entire preS1 region, whereas 1 line (AL9) recognized only the peptide representing the entire amino acid sequence of the preS2 region
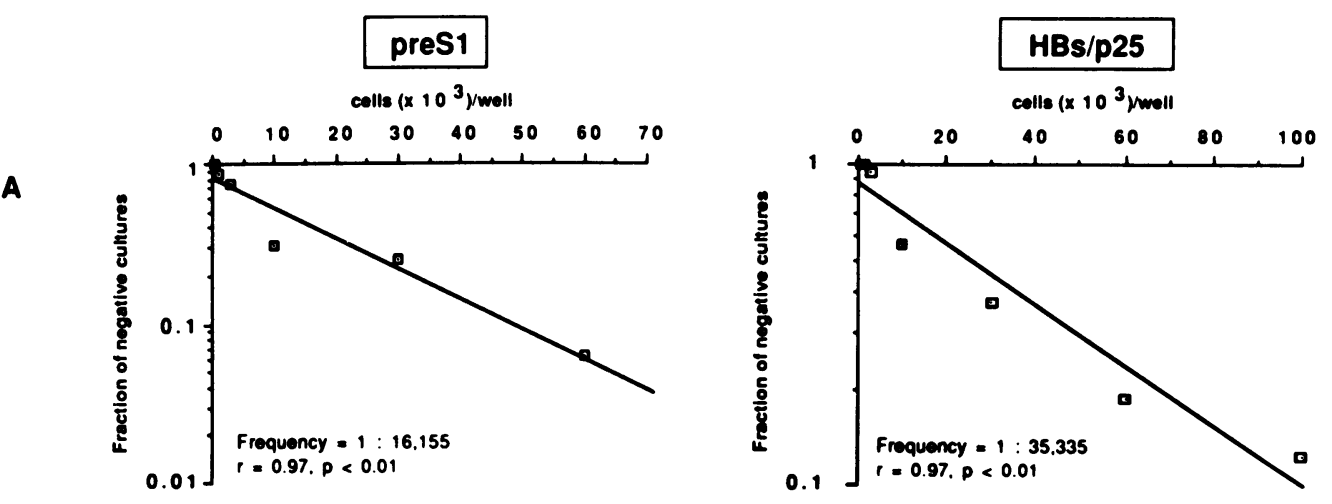

Figure 1. Limiting dilution analysis of the $T$ cell response to HBV envelope antigens. (A) Analysis of the frequency of preS1 and HBs/p25 responsive $T$ cells in the peripheral blood of vaccine recipient 12 . (B) Analysis of the frequency of $\mathrm{S}+$ preS2+preS1 and HBs/p25 responsive T cells in vaccine recipient 3 . $r$, correlation coefficient; $P$, probability that data conform to Poisson distribution kinetics with a single cell limiting. For the analysis of the $T$ cell response to $\mathrm{HBs} / \mathrm{p} 25$ in $\mathrm{A}$ and $\mathrm{S}+$ preS2+preS1 in B not only a single hit model but also a two hit model provides a good representation of the results. For the $\mathrm{T}$ cell response to $\mathrm{HBs} / \mathrm{p} 25$ in $B$ the single hit provides an adequate model for the representation of the results, but data are too sparse to investigate other models appropriately. 
Table II. Proliferative Response of T Cell Lines and Clones to Plasma-derived $S+$ preS2 + preSl and to Plasma-derived and Recombinant $S / p 25$ of Different Subtype

\begin{tabular}{|c|c|c|c|}
\hline Cloned T cells & $\begin{array}{c}\text { Human S } \\
\text { + preS2 + preS1 } \\
(\text { ad + ay) }\end{array}$ & $\begin{array}{l}\text { Human } S / p 25 \\
\text { (ad) }\end{array}$ & 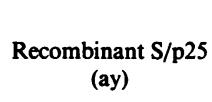 \\
\hline E2 & $\underline{27,773}(148)$ & $\underline{6,033}(32)$ & $\underline{20,955}(44)$ \\
\hline E4 & $\underline{64,755}(68)$ & $\underline{57,827}(61)$ & $\overline{74,178}(78)$ \\
\hline E5 & $\underline{32,271}$ (43) & $\underline{47,290}(23)$ & $\underline{41,254}(55)$ \\
\hline E6 & $\underline{45,709}(86)$ & $\underline{5,108}(31)$ & $\underline{23,928}$ (45) \\
\hline E8 & $\underline{21,097}$ (34) & $104(1.6)$ & $27(1.2)$ \\
\hline E9 & $\underline{23,941}$ (17) & $\underline{12,711}(10)$ & $\underline{35,497}(25)$ \\
\hline E10 & $\underline{9,839}$ (28) & 435 & $620(1.8)$ \\
\hline E11 & $\underline{21,762}(64)$ & $\underline{3,699}(108)$ & $\underline{16,125}(20)$ \\
\hline E16 & $\underline{39,507}$ (26) & 44,729 & $\underline{56,804}(37)$ \\
\hline E19 & $\underline{41,615}(57)$ & $\underline{37,771}(52)$ & $\underline{39,849}$ (55) \\
\hline E23 & $\underline{37,562}(63)$ & $\underline{20,953}(152)$ & $\underline{20,118}(34)$ \\
\hline E25 & $\underline{44,348}$ (96) & $382(1.8)$ & $488(1)$ \\
\hline E27 & $\underline{34,838}$ (129) & $288(1)$ & $464(1.7)$ \\
\hline E29 & $\underline{29,827}(40)$ & $516(1.4)$ & $253(0.7)$ \\
\hline E8-24 & $\underline{2,935}$ (17) & $164(0.9)$ & N.T. \\
\hline E16-3 & $\underline{5,298}(10)$ & $\underline{9,330}(17)$ & $\underline{7,915}$ (14) \\
\hline ALl & $\underline{9,202}(33)$ & $\underline{22,269}(79)$ & N.T. \\
\hline AL4 & $\underline{9,488}(11)$ & $\underline{6,166}(7)$ & N.T. \\
\hline AL9 & $\underline{3,510}(21)$ & $54(0.3)$ & $194(1.2)$ \\
\hline AL11 & $\underline{5,104}(19)$ & $\underline{12,208}(44)$ & $\underline{14,475}(53)$ \\
\hline AL18 & $\underline{2,518}$ & $\underline{2,631}(45)$ & N.T \\
\hline AL20 & $\underline{8,536}(9)$ & $\underline{15,129}$ (17) & $\underline{6,458}(7)$ \\
\hline AL29 & $\overline{1,254}(48)$ & $\overline{1,126}(43)$ & N.T. \\
\hline AL30 & $\underline{2,246}$ (11) & $\underline{3,648}(10)$ & N.T. \\
\hline AL33 & $\overline{7,936}(22)$ & $\overline{4,256}(12)$ & N.T. \\
\hline AT1 & $8,528(21)$ & $\underline{4,200}(10)$ & $\underline{17,581}$ (17) \\
\hline AT2 & $\underline{8,633}$ (19) & $\underline{12,730}(28)$ & $\underline{17,697}$ (39) \\
\hline AT3 & $\underline{2,855}(84)$ & $\underline{2,630}(77)$ & N.T. \\
\hline AT5 & $\underline{18,985}(72)$ & $\underline{14,624}(56)$ & N.T. \\
\hline AT9 & $\underline{6,011}(25)$ & $71(0.3)$ & $210(0.9)$ \\
\hline AT20 & $13,014(42)$ & $214(0.5)$ & 847 (2.7) \\
\hline AL4-1 & $\overline{14,615}$ (39) & $\underline{18,061}(48)$ & N.T \\
\hline AL4-2 & $\underline{22,892}$ (21) & $\underline{27,931}(26)$ & N.T. \\
\hline AL4-3 & $\underline{34,795}$ (31) & $\underline{34,801}(31)$ & N.T. \\
\hline
\end{tabular}

HBV envelope responsive T cells $\left(5 \times 10^{4}\right)$ were stimulated with varying concentrations of antigen $(0.01,0.1,1$, and $5 \mu \mathrm{g} / \mathrm{ml})$ in the presence of autologous APC. Proliferation in the presence of optimal concentrations $(5 \mu \mathrm{g} / \mathrm{ml})$ is shown. The results are expressed as the mean counts per minute of three replicate determinations. The SI is in parentheses since the results refer to different experiments. Underlined values represent significant proliferative responses.

(Table III). None of the S/p25-responsive lines recognized these preS peptides (data not shown).

Two lines specific for S/p25 (E16 and AL4) and one specific for preS1 (E8) were selected for additional cloning at 0.5 cells/well. Of a total of $163 \mathrm{~T}$ cell clones generated, 17 (7 derived from line E16, 3 from line E8, and 7 from line AL4) were tested for their proliferative response to HBV envelope antigens, and all showed the same envelope region specificity (Table II) and phenotype of the original parental line. By application of a conditional probability argument, the two sequential cloning steps herein described yielded 99, 95, and

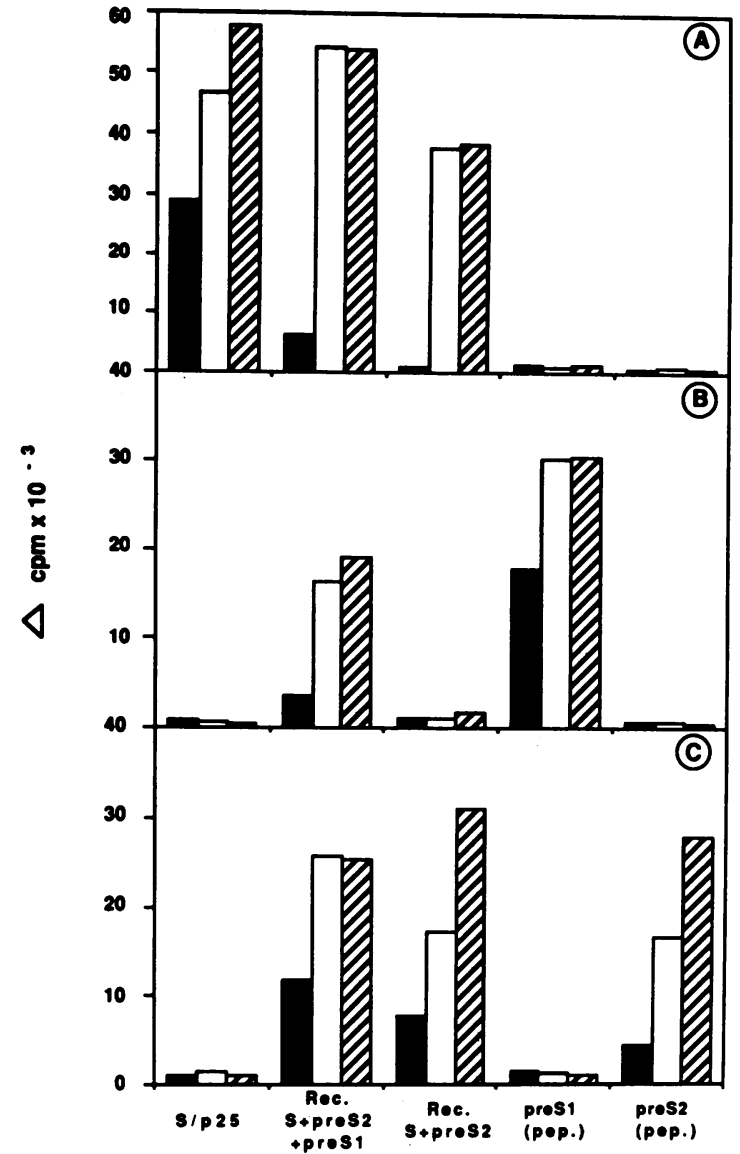

Figure 2. Dose-dependent proliferative response to different HBV envelope antigen preparations. T cells $\left(5 \times 10^{4}\right)$ from three representative cloned lines (E4, S/p25 specific in $A ; \mathrm{E} 27$, preS1 specific in $B$; AL9, preS2 specific in $C$ ) were stimulated with different concentrations of antigen in the presence of mytomicin C-treated autologous PBMC as APC $\left(1 \times 10^{5}\right)$ for $3 \mathrm{~d}$. The results are expressed as counts per minute corrected for background $(\Delta c p m) . \pm, 0.1 \mu \mathrm{g} / \mathrm{ml} ; \square, 1 ; 0,5$.

98\% probability of monoclonality for the $\mathrm{T}$ cell populations derived from E16, E8, and AL4, respectively.

\section{Discussion}

Production of anti-HBs antibodies after vaccination with plasma-derived or recombinant $\mathrm{HBV}$ envelope antigen preparations appears to confer protection against $\mathrm{HBV}$ infection.

Table III. PreS Specificity of the S/p25 Nonresponsive Lines

\begin{tabular}{ccccc}
\hline Cloned T cells & $\begin{array}{c}\text { Recombinant } \\
\text { S + preS2 + preS1 }\end{array}$ & $\begin{array}{c}\text { Recombinant } \\
\text { S + preS2 }\end{array}$ & $\begin{array}{c}\text { preS1 } \\
\text { (peptide) }\end{array}$ & $\begin{array}{c}\text { preS2 } \\
\text { (peptide) }\end{array}$ \\
\hline E8 & $\underline{\mathbf{8 , 6 3 8}(20)}$ & $\mathbf{4 8 5}(0.8)$ & $\underline{20,577}(47)$ & $100(1)$ \\
E10 & $\underline{12,270}(43)$ & $232(0.8)$ & $\underline{12,651}(27)$ & $551(1.1)$ \\
E25 & $\underline{10,051}(56)$ & $103(0.6)$ & $\underline{6,043}(29)$ & $621(0.7)$ \\
E27 & $\underline{19,210}(16)$ & $1,470(1.2)$ & $\underline{30,574}(24)$ & $623(0.5)$ \\
E29 & $\underline{\mathbf{8 , 5 9 6}}(103)$ & $230(2.7)$ & $\underline{4,335}(24)$ & $303(1.7)$ \\
AL9 & $\underline{25,647}(20)$ & $\underline{31,163(24)}$ & $1,263(1)$ & $\underline{27,809}(21)$ \\
AT9 & $\underline{5,836}(19)$ & $366(1.2)$ & N.T & N.T. \\
AT20 & $\underline{6,272}(36)$ & $123(0.7)$ & $\underline{12,573(73)}$ & $234(1.3)$
\end{tabular}

Experimental conditions are the same described in the legend of Table II. 
It is well known that helper $\mathrm{T}$ cell activation plays an essential role for neutralizing antibody synthesis, since B cells are usually induced to produce antiviral specific antibodies only after activation of antigen-specific CD4+ $T$ cells. While the functional features of HBsAg-specific CD4+ T cells isolated from vaccine recipients have already been analyzed in great detail (27-29), the $T$ cell response to preS antigens during natural $\mathrm{HBV}$ infection and after vaccination has been poorly characterized (16-20).

Taking advantage of the presence of preS determinants in some widely used plasma-derived vaccine preparations (Pasteur vaccine) that have been shown to induce production of detectable levels of anti-preS antibodies in a proportion of recipients $(9,15)$, we analyzed the $T$ cell response to the $S$ and preS envelope antigens of HBV elicited by these vaccines. For this purpose we used antigen preparations containing well-determined amounts of S, preS2, and preS1 region encoded polypeptides in an attempt to characterize the whole repertoire of different $T$ cell specificities induced by the immunizing vaccine in the recipient individuals.

14 subjects who were high responders to vaccination in terms of in vivo anti-HBs specific antibody production were initially studied for their in vitro $T$ cell responsiveness to $\mathrm{S} / \mathrm{p} 25$, preS1, and preS2.

All subjects showed detectable levels of $T$ cell sensitization to $S / p 25$, whereas significant $T$ cell response to preS2 was observed in only one vaccine recipient.

These results are not surprising if we consider that preS determinants represent $<2 \%$ of the total HBV envelope antigens contained in the Pasteur vaccine, which mainly consists of $S$ region encoded polypeptides.

In contrast, $>50 \%$ of the vaccine recipients demonstrated a $\mathrm{T}$ cell proliferative response to preS1 sequences, which are present in low quantity in the immunizing vaccine. These findings suggest that preS1 may be highly immunogenic at the $T$ cell level in man.

Additional evidence supporting the notion that preS1 is a strong $T$ cell immunogen came from the results of the limiting dilution experiments. Two vaccine recipients who showed a significant $\mathrm{T}$ cell response to preS1 were selected to evaluate the real magnitude of this phenomenon by limiting dilution analysis of the circulating HBV envelope-responsive $T$ cells.

In the first vaccine recipient (No. 12, Table I) frequency of preS1-specific circulating $\mathrm{T}$ cells was surprisingly higher than that of $\mathrm{S} / \mathrm{p} 25$ reactive $\mathrm{T}$ cells $(1: 16,155$ vs. 1:35,335; Fig. $1 A)$. This finding confirmed that preS1-responsive $\mathrm{T}$ cells were not only present in the peripheral blood of this subject but also represented at a high level.

Limiting dilution analysis was performed in the second vaccine recipient (No. 3, Table I) using hS/p25 and $\mathrm{hS}+$ preS2+preS1, assuming that a higher frequency of $\mathrm{T}$ cells responsive to the latter preparation should be due to the activation of preS-specific $T$ cells. In line with the results of the first limiting dilution experiment, frequency of $T$ cells responsive to $S / p 25$ was less than one-third that of $T$ cells responsive to hS+preS2+preS1, confirming the high frequency of circulating preS-region responsive $T$ cells in this second vaccine recipient (Fig. $1 B$ ).

The frequency of human peripheral blood $\mathrm{T}$ cell precursors specific for other antigens has been previously documented by limiting dilution analysis in several systems. Published frequency of TT reactive $\mathrm{T}$ cells in immune individuals ranged from $\sim 1: 750$ to $1: 11,500(30)$. Similar frequencies were ob- served for $\mathrm{T}$ cells specific for purified protein derivative (30, 31), streptokinase/streptodornase (32), and keyhole limpet hemocyanin (33) in immune donors. Frequencies between $1: 3,656$ and $1: 47,501$ were found in response to $M$. leprae in patients with tuberculoid and lepromatous leprosy (31).

Our results demonstrate that peripheral blood preS1-specific $T$ cells may be more abundant than S/p25-specific $T$ cells in some vaccine recipients of an HBV vaccine containing only trace quantities of the preSl antigen. This frequency appears to be close to that induced by $T$ cell immunogens as powerful as TT and purified protein derivative administered at optimal doses.

The significant level of $\mathrm{T}$ cell proliferation to $\mathrm{S}$ and preS determinants observed in some vaccine recipients prompted us to explore the possibility of producing $\mathrm{S}$ - and preS-responsive $\mathrm{T}$ cell clones from these individuals.

29 oligoclonal lines, responsive to the antigen preparation used for cloning containing $\mathrm{hS}+$ preS2+preS1, were produced from two vaccine recipients. 21 were S/p25 specific, 7 preS1 specific, and 1 preS2 specific since they selectively recognized the amino acid sequences encoded by the $S$, preS1, and preS2 regions of the $\mathrm{HBV}$ envelope, respectively.

It is remarkable that $\sim 25 \%$ of the HBV envelope-specific $T$ cell lines ( 7 of 29 ) isolated by cloning from two individuals immunized with a vaccine containing very low amounts of preS determinants $(\leq 20 \mathrm{ng} / \mu \mathrm{g} \mathrm{HBsAg}$ ) were preS1 specific. These results appear even more significant if we consider that preS1 sequences were also present in very low quantities in the antigen preparation used for cloning ( $\sim 1 \%$ of the total HBsAg). Therefore, these findings provide additional support to the evidence that preS1 is highly stimulatory for human $\mathrm{T}$ cells.

In conclusion, the present study illustrates that immunization with very low quantities of preS1 can induce significant $\mathrm{T}$ cell sensitization which is detectable as in vitro $T$ cell proliferation to preS1. In addition, results of limiting dilution analysis and $\mathrm{T}$ cell cloning confirm that preS1-specific $\mathrm{T}$ cells may be present with high frequency in the peripheral blood of a proportion of preS1 high responder subjects. Taken together, all these observations suggest that the product of the preS1 region of the HBV envelope is a very good $\mathrm{T}$ cell immunogen in man, confirming previous reports in the mouse system (12).

Functional analysis of $\mathrm{T}$ cell lines and clones described in this study could help to establish whether inclusion of higher quantities of preS1 sequences in the hepatitis B vaccine can improve its efficacy. With respect to this matter, it also remains to be determined whether the preS1 antigen is similarly immunogenic in low responders to the present plasma-derived hepatitis $B$ vaccine.

\section{Acknowledgments}

The authors would like to thank Dr. A. Alberti, Padova University, Padova, Italy, for quantitation of preS1 and preS2 reactivities in the plasma-derived antigen preparations; Sorin Biomedica Spa, Saluggia, Italy, for supplying the plasma-derived preparation containing S+preS2+preS1; Drs. R. W. Ellis, W. J. Miller, and R. A. Sitrin, Merck Sharp and Dohme, West Point, PA, for providing recombinant S+preS2+preS1, S+preS2, and preS2 and preS1 synthetic peptides; Prof. W. H. Gerlich and Dr. M. Seifer, University of Göttingen, FRG, for recombinant $\mathbf{S}+$ preS2 and $\mathbf{S}+$ preS2+preS1 used in the preliminary experiments; Dr. F. V. Chisari, Scripps Clinic and Research Foundation, La Jolla, CA, and Dr. R. E. Louie, Cutter Laboratories, Berkeley, $\mathrm{CA}$, for plasma-derived S/p25 of ad and ay subtypes; and Amgen, 
Thousand Oaks, CA, for recombinant $S / p 25$. We are particularly indebted to Dr. J. Koziol, Scripps Clinic and Research Foundation, La Jolla, CA, for statistical analysis.

This work was supported in part by the Ministry of the National Education, Project on liver cirrhosis, Italy, and by National Institutes of Health grant AI-26626-01. This is publication number 5718-BCR from the Research Institute of Scripps Clinic.

\section{References}

1. Hilleman, M. R., E. B. Buynak, W. J. McAleer, A. A. McLean, P. J. Provost, and A. A. Tytell. 1982. In Viral Hepatitis. W. Szmuness, H. J. Alter, and J. E. Maynard, editors. The Franklin Institute Press, Philadelphia. 385-392.

2. McAleer, W. J., E. B. Buynak, R. Z. Maigetter, D. E. Wampler, W. J. Miller, and M. R. Hilleman. 1984. Human hepatitis B vaccine from recombinant yeast. Nature (Lond.). 307:178-180.

3. Neurath, A. R., S. B. H. Kent, N. Strick, and K. Parker. 1986. Identification and chemical synthesis of a host cell receptor binding site on hepatitis B virus. Cell. 46:429-436.

4. Ohnuma, H., K. Takahashi, S. Kishimoto, A. Machida, M. Imai, S. Mishiro, S. Usuda, K. Oda, T. Nakamura, Y. Miyakawa, and M. Mayumi. 1986. Large hepatitis B surface antigen polypeptides of Dane particles with the receptor for polymerized human serum albumin. Gastroenterology. 90:695-701.

5. Alberti, A., P. Pontisso, E. Schiavon, and G. Realdi. 1984. An antibody which precipitates Dane particles in acute hepatitis type B: relation to receptor sites which bind polymerised human serum albumin on viral particles. Hepatology. 4:220-226.

6. Budkowska, A., P. Dubrevil, F. Capel, and J. Pillot. 1986. Hepatitis B virus pre-S gene-encoded antigenic specificity and anti-pre-S antibody: relationship between anti-pre-S response and recovery. Hepatology. 6:360-368.

7. Okamoto, H., S. Usuda, M. Imai, K. Tachibana, E. Tanaka, T. Kumakura, M. Itabashi, E. Takai, F. Tsuda, T. Nakamura, Y. Miyakawa, and M. Mayumi. 1986. Antibody to the receptor for polymerized human serum albumin in acute and persistent infection with hepatitis B virus. Hepatology. 6:354-359.

8. Klinkert, M., L. Theilmann, E. Pfaff, and H. Schaller. 1986. Pre-S1 antigens and antibodies early in the course of acute hepatitis B virus infection. J. Virol. 58:522-525.

9. Alberti, A., P. Pontisso, G. Tagariello, D. Cavalletto, L. Chemello, and F. Belussi. 1988. Antibody response to pre-S2 and hepatitis B virus induced liver damage. Lancet. i:1421-1424.

10. Milich, D. R., G. B. Thornton, A. R. Neurath, S. B. Kent, M. L. Michel, P. Tiollais, and F. V. Chisari. 1985. Enhanced immunogenicity of the pre-S region of hepatitis B surface antigen. Science (Wash. DC). 228:1195-1199.

11. Neurath, A. R., S. B. H. Kent, N. Strick, D. Stark, and P. Sproul. 1985. Genetic restriction of immune responsiveness to synthetic peptides corresponding to sequences in the pre-S region of the hepatitis B virus (HBV) envelope gene. J. Med. Virol. 17:1 19-125.

12. Milich, D. R., A. McLachlan, F. V. Chisari, S. B. H. Kent, and G. B. Thornton. 1986. Immune response to the pre-S(1) region of the hepatitis B surface antigen (HBsAg): a pre-S(1)-specific $\mathrm{T}$ cell response can bypass nonresponsiveness to the pre-S(2) and $S$ regions of $\mathrm{HBsAg}$. J. Immunol. 137:315-322.

13. Itho, Y., E. Takai, H. Ohnuma, K. Kitajima, F. Tsuda, A. Machida, S. Mishiro, T. Nakamura, Y. Miyakawa, and M. Mayumi. 1986. A synthetic peptide vaccine involving the product of the pre-S(2) region of hepatitis B virus DNA: protective efficacy in chimpanzees. Proc. Natl. Acad. Sci. USA. 83:9174-9178.

14. Neurath, A. R., N. Strick, S. B. H. Kent, W. Offensperger, S. Wahl, J. K. Christman, and G. Acs. 1985. Enzyme-linked immunoassay of pre-S gene-coded sequences in hepatitis B vaccines. J. Virol. Methods. 12:185-192.

15. Neurath, A. R., S. B. H. Kent, N. Strick, and Hepatitis B Vaccine Trial Study Groups. 1986. Detection of antiviral antibodies with predetermined specificity using synthetic peptide- $\beta$-lactamase conjugates: application to antibodies specific for the preS region of hepatitis B virus envelope proteins. J. Gen. Virol. 67:453-461.

16. Ferrari, C., A. Penna, P. Sansoni, T. Giuberti, T. M. Neri, F. V. Chisari, and F. Fiaccadori. 1986. Selective sensitization of peripheral blood $\mathrm{T}$ lymphocytes to hepatitis B core antigen in patients with chronic active hepatitis type B. Clin. Exp. Immunol. 67:457-506.

17. Ferrari, C., A. Penna, T. Giuberti, M. J. Tong, E. Ribera, F. Fiaccadori, and F. V. Chisari. 1987. Intrahepatic, nucleocapsid antigen-specific $\mathrm{T}$ cells in chronic active hepatitis B. J. Immunol. 139:2050-2058.

18. Vento, S., S. Ranieri, R. Williams, E. G. Rondanelli, C. J. O'Brien, and A. L. W. F. Eddleston. 1987. Prospective study of cellular immunity to hepatitis-B-virus antigens from the early incubation phase of acute hepatitis B. Lancet. ii:119-122.

19. Steward, M. W., B. M. Sisley, C. Stanley, S. E. Brown, and C. R. Howard. 1988. Immunity to hepatitis B: analysis of antibody and cellular responses in recipients of a plasma-derived vaccine using synthetic peptides mimicking $\mathrm{S}$ and pre-S regions. Clin. Exp. Immunol. 71:19-25.

20. Jin, Y., W. K. Shih, and I. Berkower. 1988. Human T cell response to the surface antigen of hepatitis $B$ virus ( $\mathrm{HBsAg}$ ). Endosomal and nonendosomal processing pathways are accessible to both endogenous and exogenous antigen. J. Exp. Med. 168:293-306.

21. Milich, D. R., D. L. Peterson, G. G. Leroux-Roels, R. A. Lerner, and F. V. Chisari. 1985. Genetic regulation of the immune response to hepatitis B surface antigen $(\mathrm{HBsAg})$. VI. T cell fine specificity. J. Immunol. 134:4203-4211.

22. Ellis, R. W., P. J. Kniskern, and A. Agopian. 1988. Preparation and testing of a recombinant-derived hepatitis $B$ vaccine consisting of preS2+S polypeptides. In Viral Hepatitis and Liver Disease. A. Zuckerman, editor. Alan R. Liss, Inc., New York. 1079-1086.

23. Kniskern, P. J., A. Agopian, P. Burke, N. Dunn, E. A. Emini, W. J. Miller, S. Yamazaki, and R. W. Ellis. 1988. A candidate vaccine for hepatitis B containing the complete viral surface protein. Hepatology. 8:82-87.

24. Koziol, J. A., C. Ferrari, and F. V. Chisari. 1987. Evaluation of monoclonality of cell lines from sequential dilution assays. J. Immunol. Methods. 105:139-143.

25. Lefkovits, I., and H. Waldmann. 1979. Analysis of cells in the immune system. Cambridge University Press, Cambridge, UK. 324 pp.

26. Taswell, C. 1986. Limiting dilution assays for the separation, characterization, and quantification of biologically active particles and their clonal progeny. In Cell Separation: Selected Methods and Applications. Pretlow and Pretlow, editors. Academic Press, New York.

27. Celis, E., P. C. Kung, and T. W. Chang. 1984. Hepatitis B virus-reactive human $\mathrm{T}$ lymphocyte clones: antigen specificity and helper function for antibody response. J. Immunol. 132:1511-1516.

28. Celis, E., and T. W. Chang. 1984. Antibodies to hepatitis B surface antigen potentiate the response of human $T$ lymphocyte clones to the same antigen. Science (Wash. DC). 224:297-299.

29. Celis, E., D. Ou, and L. Otvos, Jr. 1988. Recognition of hepatitis B surface antigen by human T lymphocytes. Proliferative and cytotoxic responses to a major antigenic determinant defined by synthetic peptides. J. Immunol. 140:1808-1815.

30. VanOers, M. H. J., J. Pinkstern, and W. P. Zeijlemaker. 1978. Quantification of antigen-reactive cells among human T lymphocytes. Eur. J. Immunol. 8:477-484.

31. Brett, S. J., A. E. Kingston, and M. J. Colston. 1987. Limiting dilution analysis of the human $\mathrm{T}$ cell response to mycobacterial antigens from BCG vaccinated individuals and leprosy patients. Clin. Exp. Immunol. 68:510-520.

32. Sohnle, P. G., and C. Collins-Lech. 1981. Lymphocyte transformation and the number of antigen-responsive cells in humans. $J$. Immunol. 127:612-615.

33. Gebel, H. M., J. R. Scott, C. A. Parvin, and G. E. Rodey. 1983. In vitro immunization to $\mathrm{KLH}$. II. Limiting dilution analysis of antigen-reactive cells in primary and secondary culture. J. Immunol. 130:29-32. 